\title{
Dr. Manohar Hariram Keswani
}

Dr. Manohar Hariram Keswani was born in Sukker, which is presently in Sind, Pakistan, on 8 April 1931. In 1947, the family was devastated and impoverished by the partition of India and migrated to Salem in South India. Dr. Keswani graduated from the Ferguson College in Poona in 1948 and did his professional training at The Seth Gowardhandas Sunderdas Medical College and King Edward VII Memorial Hospital in Mumbai.

Having qualified as a general surgeon in 1957, he applied for the much coveted tho racic surgical post at the Christian Medical College, Vellore under Professor Reeve H. Betts, who was then blazing a trail in thoracic and cardiac surgery. In a couple of months, Dr. Keswani, who in his spare time had watched Dr. McPherson operate in the plastic surgical unit, asked for a transfer to McPherson's

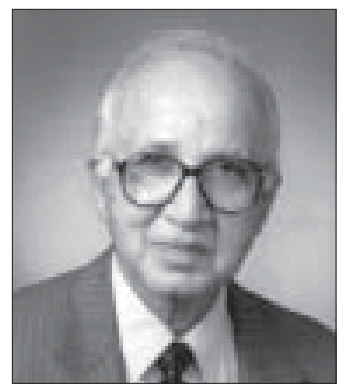

unit as he said "I fell in love with the work". His first request was denied; however, the second time he asked for a transfer, it was granted. From here, he obtained his basic training with McPherson in plastic surgery and came in contact with Paul Brand and Noshir Antia who were working on rehabilitating patients suffering from leprosy.

In 1960, at the suggestion of Dr. Antia, he came back to Bombay and joined the J.J. Group of Hospitals as an assistant to Dr. Rustom Irani, who was pioneering Paediatric surgery in Western India; he then moved to the Tata Department of Plastic Surgery, J.J. Group of Hospitals as Assistant Professor to Dr. Antia. This was the beginning of Plastic Surgery in India. Sir Harold Gillies was with Noshir Antia at the J.J. Group of Hospitals, and 
Mr. Eric Peet was with Charles Pinto at the KEM Hospital. Dr. Keswani played a cardinal role in establishing the Tata Department on a solid basis where he became known for his industry and craftsmanship.

In 1964, Dr. Keswani went for further training to Birmingham and then to the University of Texas and to the US Army Research Hospital in the United States of America. In 1975, he set up the first paediatric burns unit in the country at the Bai Jerbai Wadia Hospital for children in Bombay and also the first skin bank of India in 1978. He organized the first Afro Asian Conference on Burns in 1981. In 1992, he organized and established a state of the art burns department at the Masina Hospital, which was called the Kharas Memorial Burns Department. In 1998, he planned and helped to set up a 16-bed burns department at the Jubilee Mission Hospital and Medical College in Trichur, Kerala, in South India. In the year 2002, he ventured on a gigantic project and ultimately succeeded in starting the National Burns Centre at Airoli in New Bombay.

As Founder-Secretary of the Burns Association of India, the Indian Burns Research Society (the 3R Society) and the National Society of Equal Opportunities for the Handicapped, hesank his own resourcesin the propaganda for the prevention of Burns and made films directed by Mr. Shyam Benegal and Mr. Alyque Padamsee. Distressed by the suffering that burns caused, the prevention of burns became a passion with this man and he sent out a strong message to women on the safety of their kitchens and to school children to "pour water on burns". He designed and propagated the use of boiled potato peel bandages as a cheap and useful burns dressing and the use of curds to debride a burns wound and prepare it for grafting.

Dr. Keswani's work on burns was internationally recognized in Britain, America and Europe by bestowing upon him their three coveted awards: the James Lang Memorial Prize of the British Burns Association; the Evans Memorial Award of the American Burns Association and the Whitaker Award of the European Burns Association.

In manyaspects, Manohar Keswani was a really remarkable man, who was recognized and lauded for his work on burns. Few knew about his prowess, versatility and innovative skills in general plastic surgery. His primary and secondary cleft work, his work on the hypospadias, the results he achieved with his vaginoplasties and his pioneering sex-change operations and the skill with which he could cut a large skin graft to mathematical precision will long be remembered by his close associates.

I once gave him a particularly difficult secondary cleft lip correction to do. He laboured through the operation for over three hours, undid the whole lip twice; at the end of it, he gave the child a lovely Cupid's bow, well-matched philtral columns, a full vermillion and a dead symmetrical nose, following no set plan. At the end of this operation, I asked him, how did you do it Manohar? His answer was, "I really don't know.". He was improvising all the time.

A great connoisseur of art, he had both the hand and the heart of an artist. But above all, I shall remember him as a gentleman par-excellence, patient, caring and ethically above reproach. The plastic surgical fraternity and those who shared lovely memories with Manohar Keswani, both on and off the table, will miss this man.

Dr. Sunil Keshwani, his son is currently active with National Burn Centre in Navi Mumbai and the Eric Kharas Burn Centre

H. S. Adenwalla Department of Plastic Surgery, Jubilee Mission Hospital, Thrissur, Kerala, India 